\title{
GRAPHIC DESIGN OF “GREEN MISSION” EDUCATION GAME USING SOFTWARE BASED ON VECTOR
}

\author{
Nuryanti \\ Information Systems Department, Faculty of Computer Science \\ Soegijapranata Catholic University, Indonesia \\ yanti7566@gmail.com \\ Ridwan Sanjaya \\ Information Systems Department, Faculty of Computer Science \\ Soegijapranata Catholic University, Indonesia \\ ridwan@unika.ac.id \\ FX. Hendra Prasetya \\ Information Systems Department, Faculty of Computer Science \\ Soegijapranata Catholic University, Indonesia \\ hendra@unika.ac.id
}

\begin{abstract}
An educational game is a digital game in which its design uses the education elements and it supports teaching and learning by using technology of interactive media. Generally, an educational game has a fun look, an easy-to-use menu, as well as color combinations that are used by GUIbased (Graphic User Interface) so as to appeal the users. It is undeniable that the human brain tends to more quickly capture learning through visual images rather than writings. Therefore, graphic design of an educational game becomes one of the important points. Software applications become one of the solutions in making game design, one of which is a vector-based software application. Varioussoftware applications can be used in accordance with the function and utility, but in general the way the software works almost same.
\end{abstract}

Keywords: Educational Game, Software, Vector

\section{INTRODUCTION}

An educational game can build character and convey information as games currently become one part in the life of people ranging from children to adults. Based on a study, the game industry begins to lead educational values. It is intended that in playing the game is not only entertainment solely obtained but the element of knowledge as a value added.

One of the games to be designed is titled "Green Mission”. The game is a forestry theme that takes concrete concepts of the current state of forests where many fires and forest destruction occur which lead to a decrease in forest cover. The design of this game focuses on fire fighting, forest replanting, and prevention of logging. The design is done using vector-based software where the use of this type of software applications is quite easy.

\section{THEORETICAL FOUNDATION}

2.1 Educational Games and Benefits

Educational games have a variety of benefits that can be obtained by users, including: [1]

a. providing interactive elements that can stimulate the learning process

b. allowing players to experience new things such as increasing curiosity and challenges so as to stimulate in the learning process.

c. equipping players with technology and helping overcome technophobia in order 
to eliminate gender imbalances in using IT

d. helping develop skills in IT field

e. being used as a simulation that allows players to engage in activities

f. providing entertainment as it was during childhood because it can suspend reality in game play.

\subsection{Education Game Criteria}

According to Malone and Lepper, there are 4 key characteristics to formulate education, namely: [2]

a. Challenge

A game must have a level of difficulty where the design must have short-term and long-term goals, have uncertain outcomes, and have constructive and constructive feedback.

b. Curiosity

There are two forms of curiosity: sensory curiosity which is enhanced by audio variability and visual effects as well as cognitive curiosity in which players feel shocked and interested.

c. Control

Control is the determination of fate. Contains elements of possibility (must provide a responsive learning environment), choice (has some aspects of choice in the learning environment), as well as power (produces strong effects for players).

d. Fantasy

It covers emotional aspects, cognitive aspects, and endogenous aspects

\subsection{Graphic Design}

It is a form of visual communication that uses image media to convey an information or a message more effectively by taking into account aspects of function, aesthetics, etc. so that information can be conveyed. Graphic design art includes cognitive and visual skills, including typography, illustrations, photography, image processing, and layout. [3]
There is a variety of graphics software applications. One of them is vector-based software. The vector itself is an image composed of lines and geometric shapes (curves) that are independent resolution (the image remains good regardless of the resolution). Even if it is enlarged, it still does not diminish its quality and the image remains clear. The size of the resulting file is small. [5]

\subsection{CorelDraw X4}

It is vector-based image processing software developed by Corel, a Canadianbased software company. X4 version itself was released in 2008. Some of the facilities provided include:[4]

a. Cropping

Facility to cut the object area quickly

b. Table

Facility to create a table

c. Smart Fill

Facility to quickly color an object or more.

d. Complex Star

Facility to create a very complex star object that looks more varied.

e. Step and Repeat

Facility to copy the object by specifying the number of copies as well as setting the distance of the copy of the object.

f. Arrange-Order

Facility to organize the object stack by layer or something else.

g. Formatting Text Improved text formatting facility to make easier in setting text formats such as columns, paragraphs, drop caps, bullets, and so on.

\section{METHODS}

Game design is an early activity in game designing. The design can be done with different models for each game to be made. To design the Green Mission educational game, the steps can be seen in Figure 3.1 below:

\subsection{Vector-Based Software}




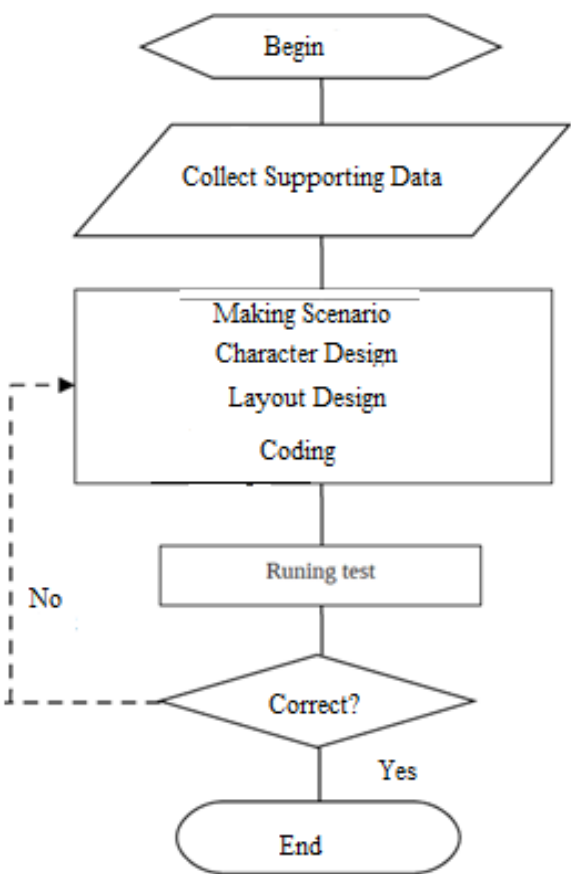

Figure 3.1 Design Flow

As for the gameplay there are various designs in the game Green Mission are classified as follows:

\section{a. Draft Opening}

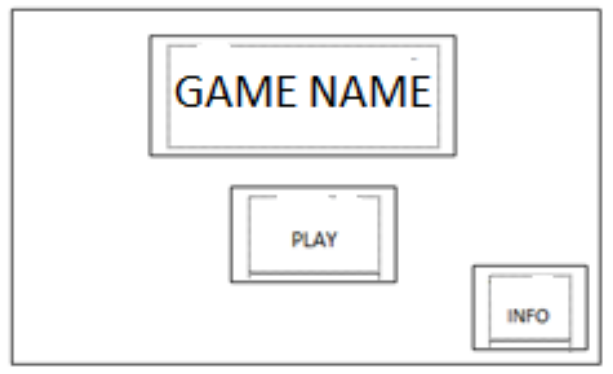

Figure 3.2 Draft Opening

b. Design of Stage Selection

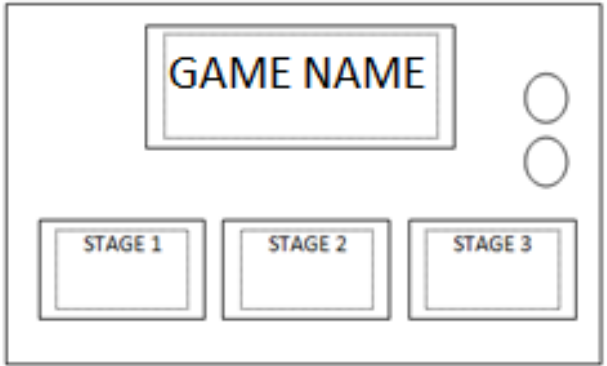

Figure 3.3Design of Stage Selection c. Design of Stage 1

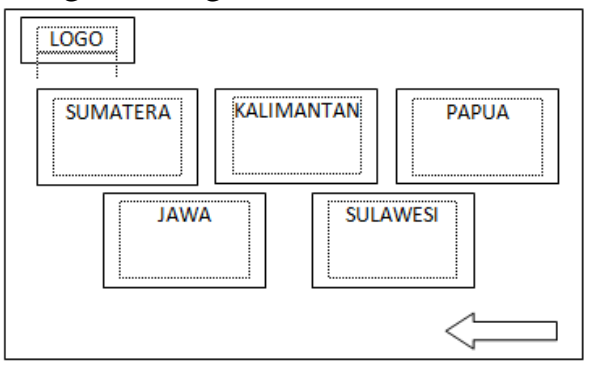

Figure 3.4Design Stage 1

d. Design of Stage 2

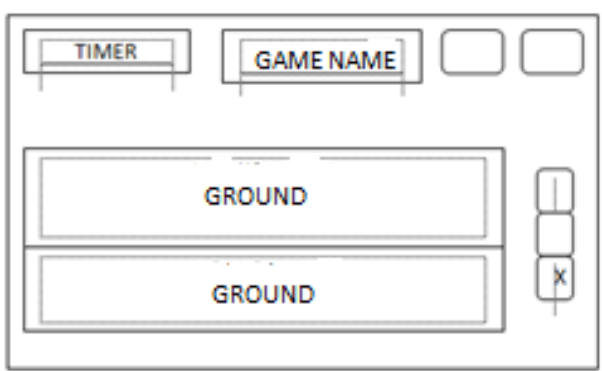

Figure 3.5Design of Stage 2

e. Design of Stage 3

\begin{tabular}{|c|c|}
\hline GaME NAME & \\
\hline TREE & \\
\hline TREE & \\
\hline \hline TIMER \\
\hline TREE \\
\hline \\
\hline
\end{tabular}

Figure 3.6Design of Stage 3

f. Exit Design

KAMU YAKIN AKAN

KELUAR?

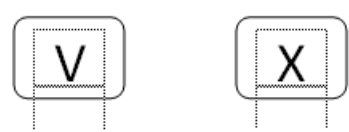

Figure 3.7Exit Design

Are you sure to quit? 


\section{RESULTS}

In the use of CorelDraw X4 application for the design of Green Mission is made with a simple 2D drawing with the following results:

a. Draft Opening

In the opening view, the design is mainly focused on game titles and play buttons. In addition, there is a cross button that serves to exit the game

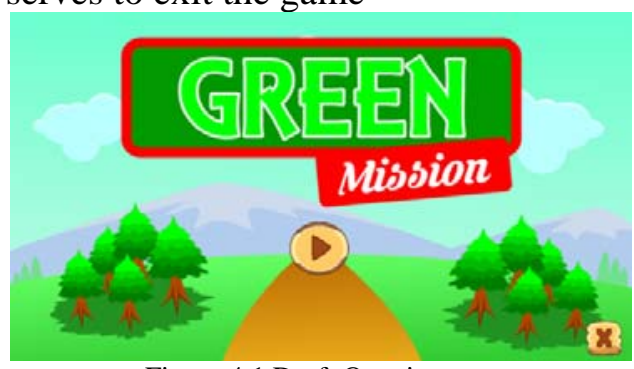

Figure 4.1 Draft Opening

\section{b. Design of Stage Selection}

In the stage selection display, the design is focused on the game name, 3 stages to play as well as the on / off button and the exit button.

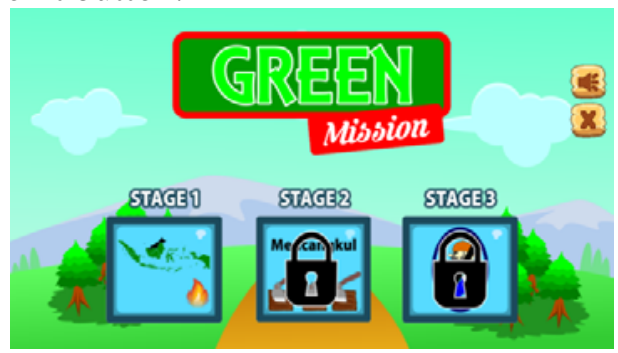

Figure 4.2 Design of Stage Selection

c. Design of Stage 1

The design is focused on 5 islands in Indonesia consisting of Sumatra, Java, Kalimantan, Sulawesi and Papua in locked state and only Sumatra island is unlocked for early game.

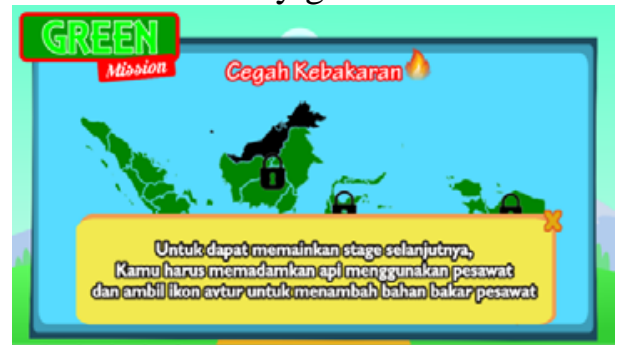

Figure 4.3 Design of Stage 1 d. Design of Stage 2

In the stage 2 display, the design is focused on the seeds of plants, water, and land. In addition there is a pause and exit button.

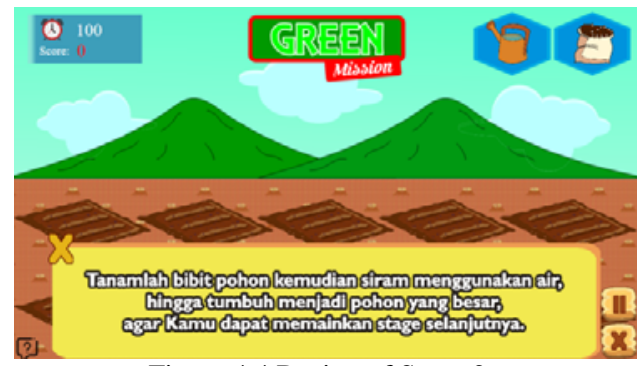

Figure 4.4 Design of Stage 2

e. Design of Stage 3

In the stage 3 display, the design is focused on displaying 3 different tree species with oxygen, timer, and pause button and exit.

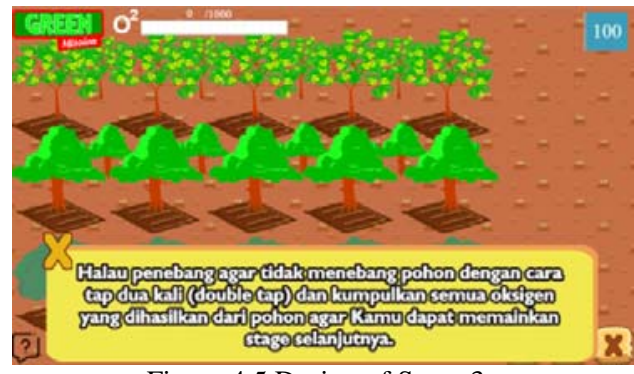

Figure 4.5 Design of Stage 3

\section{f. Exit Design}

For outward appearance, the design is focused on the choice of check or cross buttons with customizing colors.

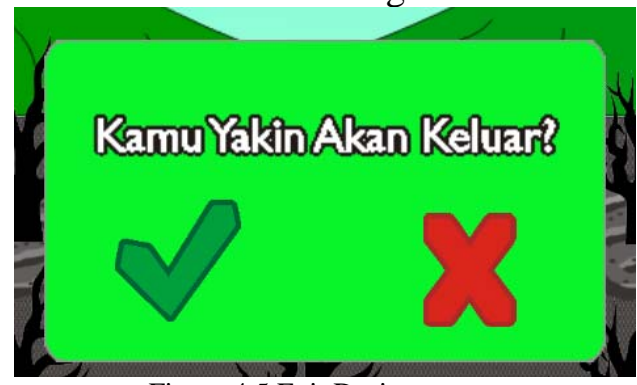

Figure 4.5 Exit Design 


\section{V.CONCLUSION}

The design produces 3 stages consisting of "Cegah Kebakaran" (prevent fire), "Mencangkul/ Reboisasi" (plow/reforest), and "Cegah Penebang" (stop the loggers) with each having 3 sublevels in it. As for the application of Green Mission design itself using CorelDraw X4 software applications. Selection of this application is based on the benefits of the resulting image can be resized and shaped so as not to disrupt and reduce the quality of the image design. In addition, the resulting small file size makes it possible to save memory.

\section{ACKNOWLEDGMENT}

I am very grateful to the lecturers of Information Systems Department, Faculty of Computer Science Soegijapranata Catholic Universitywho have guided my studies.

\section{REFERENCES}

[1] M. Giffiths, "The Educational Benefits Of Video Games," Educ. Heal., vol. 20, no. 3, pp. 47-51, 2002.

[2] T. W. Malone and M. R. Lepper, "Making Learning Fun - A Taxonomy Of Intrinsic Motivations For Learning," Learn. Instr., vol. 3, no. 31, pp. 230-240, 1987.

[3] J. Enterprise, Resep Cespleng Bisnis Desain Grafis. Jubilee Enterprise, 2016.

[4] G. Pranowo, Mastering CorelDRAW X4. Penerbit Andi, 2010.

[5] "Grafis Berbasis Vektor dan Bitmap" www.chabelithstory.wordpress.com. [Online].Available: www.chabelithstory.wordpress.com/gr afis-berbasis-vektor-dan-bitmap/.

[Accessed: 24-July-2017]. 